\title{
MEKANISME PENYALURAN KREDIT MODAL KERJA PADA PT. BANK NEGARA INDONESIA KCU BUKITTINGGI
}

\author{
Muhammad Akbar Sidik, Jhon Fernos \\ Akademi Keuangan dan Perbankan "Pembangunan" (AKBP) Padang \\ Akbarsiddiq734@gmail.com \\ jhonfernos@akbpstie.ac.id
}

\begin{abstract}
The purpose of this study was to find out how the mechanism of working capital loan distribution at PT. Bank Negara Indonesia (Persero) Tbk, KCU Bukittinggi. The research method used is a qualitative data analysis method. The type of data used is secondary data obtained from the report of Bank Negara Indonesia Bukittinggi 2016 period 2017. The results of this study are how the flow of working capital credit applications such as people business credit and entrepreneurship BNI from applications to repayment shows that the problem in working capital lending lies with the customers in terms of completeness of files and payment of credit and interest
\end{abstract}

Keywords: people business credit, entrepreneurship BNI

\section{PENDAHULUAN}

Lembaga perbankan merupakan salah satu instrument moneter yang salah satu tugas utamanya adalah memberikan kredit, selain memberikan jasa-jasa lainnya yang ada di bidang keuangan. Dalam pemberian kredit, antara bank satu dengan bank lainnya tidak sama baik dalam hal persyaratan maupun dalam prosedurnya. (Syahwier, 2013)

Pemberian kredit oleh bank mempunyai resiko kemungkinan tidak tertagih. Untuk meminimalkan hal tersebut bank merupakan prinsip 5C dalam pemberian kredit yaitu character, capacity, capital, collateral dan condition. Dari kelima prinsip diatas, collateral (jaminan) merupakan hal yang paling penting dalam melakukan pemberian kredit. Dengan adanya jaminan maka resiko kredit macet akan menjadi lebih rendah. Selain itu bank juga akan menyeleksi setiap ada pengajuan kredit yang masuk. Hal tersebut dilakukan agar resiko tidak tertagihnya piutang dapat di tekan menjadi lebih rendah. (Farisi \& Saifi, 2016)

Dalam perkembangan ekonomi yang sekarang ini kredit modal kerja mempunyai peranan yang sangat penting yaitu untuk mengembangkan perekonomian di setiap Negara dengan cara memberikan kredit modal kerja guna mengadakan rehabilitasi, perluasan usaha ataupun mendirikan suatu proyek baru dalam memenuhi kebutuhan dan memperlancar kelansungan kegiatan kredit modal kerja.(Maswatu, Pelleng, \& Tampi, 2003) 
Dalam memberikan kredit, bank harus mempunyai prinsip kehati-hatian. Kesalahan dalam memberikan kredit akan memberikan resiko yang besar bagi bank. Resiko tersebut berupa resiko tidak tertagihnya pinjaman, dan terlambatnya penerimaan pinjaman dari jadwal, sehingga menimbulkan kredit macet(Afriyeni, 2009)

Kredit modal kerja dibutuhkan bagi masyarakat karena memberikan kemudahan bagi calon debitur untuk pembelian barang-barang modal atau memberikan tambahan modal kerja untuk kebutuhan operasional sehari-hari dengan beban angsuran yang terjangkau di sistem Bank Negara Indonesia.

Pada tahun 2016 pertumbuhan kredit modal kerja tumbuh sebesar 9\% berdasarkan data dari pencatatan tutup buku tahunan BNI, pertumbuhan kredit 2016 ditopang oleh realisasi paket kebijakan pemerintah yang terbit sepanjang tahun sebelumnya, Bank Indonesia juga memastikan untuk memantau likuiditas agar tetap terkendali.

PT Bank Negara Indonesia Tbk mencatat pertumbuhan kredit modal kerja di atas industri perbankan. Berdasarkan data Bank Indonesia kredit modal kerja perbankan per november 2017 tumbuh 8,1\%, kredit modal kerja BNI pada tahun 2017 tumbuh dikisaran $11 \%$

Sedangkan pada tahun 2018 pertumbuhan penyaluran kredit modal kerja BNI bisa dikatakan membaik dibuktikan pulihnya kondisi ekonomi dengan mulai membaiknya harga-harga komoditas dan kegiatan konsumsi masyarakat yang mulai meningkat. Pada tahun 2017, BNI telah menyalurkan kredit hingga Rp 4016,09 trilliun atau tumbuh 11,81\% dibandingkan pada tahun 2018 sebesar Rp 363,18 trilliun

Salah satu kredit unggulan yang diberikan oleh Bank Negara Indonesia adalah kredit modal kerja yang di khususkan untuk para pengusaha atau pemilik usaha untuk mengembangkan usahanya.

\section{LANDASAN TEORI}

\section{Pengertian Bank}

Bank adalah badan ushaha yang menghimpun dana masyarakat dan menyalurkan dalam bentuk kredit atau dalam bentuk-bentuk lainnya untuk meningkatkan taraf hidup masyarakat banyak

Pengertian bank menurut beberapa para ahli pada dasarnya tidak terlalu memiliki perbedaan antara satu dengan yang lainnya. Dalam Hal ini pengertian bank menurut (Ii, 1998) Bank ialah salah satu badan usaha lembaga keuangan yang bertujuan memberikan kredit, dengan menggunakan peralatan pembayaran sendiri, menggunakan uang yang didapatnya dari orang lain maupun dengan jalan mengedarkan alat-alat pembayaran baru berupa uang giral.

Menurut (WijayaDenda, 2001) bank merupakan perusahaan yang bergerak dalam bidang keuangan, artinya aktivitas perbankan selalu berkaitan dalam bidang keuangan. Sehingga berbicara mengenai bank tidak terlepas dari masalah keuangan.

\section{Tujuan Bank}

Tujuan bank menurut (Herman \& Widayati, n.d.) yaitu memajukan arus tukar menukar barang danjasa, kredit mengaktifkan alat pembayaran yangidle atau 
yang tidak digunakan, kreditmenciptakan alat pembayaran baru dan kreditmengaktifkan serta meningkatkan manfaat potensiekonomi yang ada, sedangkan tujuan penyaluran kreditadalah untuk mendapatkan keuntungan yang aman, sehingga masyarakat yang meminjam danadapat memperoleh simpanannya kembali besertabunganya tanpa adanya kekhawatiran denganadanya kredit yang macet.

\section{Pengertian Kredit Modal Kerja}

Menurut (Rina Malinda, moch. Dzulkirom, n.d.) pengertian kredit modal kerja yaitu kredit modal kerja adalah kredit yang digunakan untuk keperluan meningkatkan produksi dalam operasionalnya atau merupakan kredit yang digunakan sebagai modal usaha. Biasanya kredit jenis ini berjangka waktu pendek yaitu tidak lebih dari 1 (satu) tahun. Selain itu kredit modal kerja adalah kredit yang digunakan untuk membiayai kebutuhan modal kerja nasabah.

"Modal kerja menunjukkan sejumlah dana yang tertanam pada aktiva lancar yang akan dibutuhkan dalam menjalankan aktivitas perusahaan". "Untuk kredit modal kerja, bank menyediakan fasilitas kredit bagi usaha kecil dengan plafon kredit sampai dengan Rp. 500.000.000,00 dan usaha menengah dengan plafon kredit diatas Rp. 500.000.000,00 sampai dengan Rp. 5000.000.000,00”.

\section{Analisis Pemberian Kredit Modal Kerja}

Menurut (Setyawan, 2017) prosedur pemberian kredit yaitu sebagai berikut

a. Permohonan Kredit

Tahap pertama dari prosedur pemberian kredit adalah adanya pengajuan surat permohonan kredit oleh calon debitur yang diajukan secara tertulis

b. Pengumpulan Data ‘

Setelah surat permohonan kredit diterima dari calon debitur maka dilakukan registrasi pada buku permohonan kredit.

c. Analisa Kredit

Dalam analisa kredit diperlukan adanya data-data tersebut di atas serta data lain yang diperlukan akan dilakukan oleh Account Officer (AO). Adapun data kredit pada umumnya yang dibutuhkan oleh pihak bank terdiri dari beberapa aspek yakni: hukum, manajemen, sosial ekonomi, pemasaran, teknik produksi, jaminan dan keuangan. Selanjutnya data tersebut dilakukan pemeriksaan dan verifikasi.

d. Komite kredit

Komite kredit adalah salah satu team dalam proses pemberian kredit yanganggotanya terdiri dari Account Officer atau analisis kredit, administrasi kredit dan Kepala Bagian (KABAG) Kredit serta direksi untuk pengambilan keputusan

e. Keputusan Komite Kredit

Setelah kredit diputuskan disetujui, ditolak atau ditangguhkan, maka segera dibuatkan surat penegasan atau pemberitahuan kepada pemohon. Apabila pemohon kredit disetujui maka harus dbuatkan surat penegasan kepada pemohon kredit.

f. Pengikatan kredit

Pengikatan kredit adalah pengikatan secara notariil dan peng-ikatan dibawah tangan. 
g. Penutupan ansuransi

Penutupan ansuransi yang dilakukan untuk mengurangi resiko yang kemungkinan timbul dikemudian hari.

h. Realisasi

Realisasi kredit baru dapat dilakukan apabila semua dokumen yang diberikan sudah benar.

i. Dokumentasi

Pekerjaan yang dilakukan ketika semua hal persyaratan dan berkas-berkas telah selesai dan sebagai bukti bahwa calon debitur telah bersedia dalam perarturan yang telah disepakati antara pihak bank dengan calon debitur

Menurut (Herman \& Widayati, n.d.) analisis pemberian kredit modal kerja sebagai berikut :

1. Permohonan Kredit

Dalam hal ini Debitur mengajukan permohonan kredit secara tertulis dengan melengkapi dokumen yang disyaratkan bank yaitu:

a. Fotocopy KTP dan Kartu Keluarga

b. Pas foto

c. Fotocopy Akta pendirian berikut seluruh perubahannya

d. Fotocopy perizinan usaha:

1) NPWP

2) SIUP

3) TDP

4) SITU

e. Fotocopy dokumen jaminan (sertifikat tanah, BPKB, Surat Toko, lainnya)

f. Data-data keuangan (Neraca Dan Laporan laba rugi)

g. Dokumen pendukung lainnya Dalam mengidentifikasikan permohonan kredit yang diajukan, Bank memiliki kriteria calon debitur sebagai berikut:

1) Warga Indonesia (berusia minimal 21 tahun atau telah menikah dan berakal sehat).

2) Mempunyai penghasilan yang jelas, tetap dan diyakini oleh pihak Bank.

3) Tidak tercatat daftar hitam (black list)

2. Cek Agunan/Usaha

Setelah pihak bank memeriksa kelengkapan dokumen tersebut, pihak bank melanjutkan proses pemberian kredit dengan melakukan cek agunan atau usaha debitur, tujuannya untuk mengetahui modal calon debitur. Setelah semuanya lancar pihak bank akan melakukan penilaian terhadap agunan yang dijamin oleh calon debitur, misalnya SK karyawan atau surat-surat tanah atau sertifikat rumah. Permoho nan Kredit Cek Agunan / Usaha Tahap Analisa Kredit Rekomend asi Keputu san Kredit Penandatan ganan Akad Kredit/Perj anjian Realisa si Kredit 6 
3. Tahap Analisis Kredit

Pada tahapan dapat ditarik kesimpulan, bahwa produk yang dijalankan telah mendukung aspek-aspek pengendalian manajemen kredit, dapat dijelaskan sebagai berikut :

a. aspek personal yang kompeten dan dapat dipercaya

b. aspek adanya pemisahan tugas

c. aspek prosedur otorisasi yang tepat

d. aspek dokumen dan catatan yang memadai

e. aspek kontrol fisik aktiva dan catatan

4. Rekomendasi

Apabila hasil dari analisa kredit yang dilakukan oleh defisi kredit sesuai dengan ketentuan Bank maka defisi kredit akan mengajukan kepada pimpinan untuk merekomendasikan kredit tersebut.

5. Keputusan Kredit

Dari hasil rekomendasi kredit tersebut, pihak bank memberikan keputusan apakah permohonan diterima atau ditolak.

6. Penandatanganan Akad Kredit/Perjanjian

Setelah kredit diterima, maka kedua belah pihak melakukan perjanjian kredit dengan menanda tangani akad kredit, dan pihak bank akan mengikat agunan yang diajaminkan.

7. Realisasi Kredit

Setelah itu kredit akan direalisasikan dengan persyaratan dengan membuka rekening tabungan di Bank. Setelah semuanya selesai kredit akan dicairkan dan bisa diambil oleh pihak debitur atas realisasi pemberian kredit.

\section{METODE PENELITIAN}

Dalam pengumpulan data untuk keperluan penelitian ini, digunakan metode sebagai berikut :

1. Metode Pengumpulan Data

a. Riset Perpustakaan(Library Research)

Yaitu penelitian ini dilakukan dengan cara mempelajari buku-buku, makalah-makalah, artikel-artikel, bacaan laporan-laporan dan publikasi yang berhubungan dengan objek penelitian.

b. Riset Lapangan(Field Research)

Yaitu penelitian yang mendapatkan data dengan wawancara pihakpihak yang berperan lansung dalam menyalurkan kredit modal kerja dan jawaban untuk dianalisis. Dalam penelitian ini yang menjadi objek penelitian adalah PT. Bank BNI (Persero) Tbk, KCU Bukittinggi.

2. Metode Analisa Data

Dalam menganalisa data, penulis menggunakan metode analisa data kualitatif sebagai metode penelitian, dimana metode kualitatif menggambarkan, memahami dan menjelaskan data yang diteliti selama penelitian berlansung pada PT. Bank BNI (Persero) Tbk, KCU Bukittinggi. Yang menjelaskan secara deskriptif mengenai mekanisme penyaluran kredit modal kerja yang berisikan data permohonan sampai 
pelunasan kredit modal kerja pada PT Bank Negara Indonesia (Persero) Tbk KCU Bukittinggi. Metode analisa ditinjau dari dua segi yang berbeda yaitu antara teori dan praktek sehingga dapat diketahui sejauh mana mutu pelayanannya, apakah perbedaan yang timbul menyangkut prinsip dasar konsep itu sendiri. Dengan menganalisa perbandingan, pertanyaan itu akan terjawab selanjutnya dan hasil analisa itu dipergunakan sebagai dasar pengambilan kesimpulan dan saran.

\section{HASIL PENELITIAN DAN PEMBAHASAN}

Berdasarkan data yang diperoleh PT. Bank Negara Indonesia (Persero)Tbk, KCU Bukittinggi maka selanjutnya terdapat 2 indikator penting dalam kredit modal kerja. Berikut penjelasan tersebut.

\section{a. Kredit Usaha Rakyat (KUR)}

Menurut (Purwatiningsih, 2015) pengertian kredit modal kerja yaitu

Kredit Usaha Rakyat, yang selanjutnya disingkat KUR, adalah kredit atau pembiayaan kepada Usaha Mikro Kecil Menengah (UMKM) dalam bentuk pemberian modal kerja dan investasi yang didukung fasilitas penjaminan untuk usaha produktif. Jangka waktu kredit terbagi tiga, yaitu :

a. Kredit jangka pendek,

Berjangka waktu satu tahun.

b. Kredit jangka menengah,

Berjangka waktu antara satu tahun sampai dengan tiga tahun.

c. Kredit jangka panjang,

Berjangka waktu lebih dari tiga tahun. BRI Unit memberikan jangka waktu untuk pengembalian kredit berdasarkan jenis pinjaman

b. BNI Wirausaha (BWU)

Fasliltas kredit yang yang di prioritaskan kepada pengembangan usaha seperti kredit investasi dan kredit modal kerja yang fleksibel untuk lebih memajukan usaha calon debitur, dengan plafond kisaran Rp 50 juta-Rp 1 miliar. BNI Wirausaha (BWU) mendorong usaha calon debitur dengan pemberian kredit usaha produktif kepada perorangan maupun perusahaan atau instansi pemerintahan, yang meliputi seluruh sektor ekonomi yang layak dibiayai.

Keunggulan BNI Wirausaha (BWU) :

1) Proses cepat dan persyaratan mudah

2) Jangka waktu kredit lebih panjang hingga 10 tahun

3) Suku bunga kompetitif

4) (Herman \& Widayati, n.d.)Pembayaran angsuran fleksibel

5) Batas kredit maksimal hingga Rp 1 miliar

6) Dapat Take over kredit dari bank lain.

BNI Wirausaha merupakan fasilitas pinjaman BNI tanpa jaminan yang dapat diajukan bagi siapa saja yang ingin mengembangkan usaha, dengan proses pengajuan pinjaman sangat cepat dan mudah

\section{Sistem dan prosedur pemberian kredit modal kerja yang disarankan}

Menurut (Efriani, n.d.) prosses penyaluran kredit modal kerja sebagai berikut : 


\section{Pelaksanaan Dalam Pemberian kredit}

\section{a. Permohonan Kredit}

Permohonan kredit harus diajukan secara tertulis dengan menggunakan format yang telah ditentukan oleh BPR Batang Kapas yang isinya memuat informasi lengkap mengenai kondisi pemohon atau calon nasabah, seperti berisi tentang nama pemohon, alamat pemohon, nama perusahaan, alamat perusahaan, jumlah permohonan pinjaman, jangka waktu kredit, rencana penggunaan pinjaman, agunan yang diserahkan sebagai jaminan kredit. Disamping mengajukan permohonan kredit seperti diatas tersebut calon debitur juga memenuhi beberapa kriteria dan syarat sebagai berikut :

1) Kriteria Calon Debitur

a) Warga Neagara Indonesia yang cakap hukum ( Berusia minimal 21 Tahun atau telah menikah dan berakal sehat).

b) Mempunyai usaha yang jelas dan dpat diyakini bank.

c) Tidak tercatat dalam daftar hitam dan debitur macet yang dikeluarkan oleh Bank Indonesia.

2) Persyaratan Permohonan Kredit

a) Foto copy kartu identitas diri ( KTP/SIM/PASPOR ) yang berlaku

b) Pas photo $3 \times 4$ sebanyak 3 lembar

c) Mempuanyai perizinan sesuai dengan ketentuan yang berlaku (SIUP,TDUP,SITU).

d) Mempunyai Nomor PokokWajib Pajak (NPWP) sesuai ketentuan Bank Indonesia dan menyerahkan foto copynya.

e) Untuk calon debitur yang berbentuk serta mempunyai laporan keuangan.

b. Pemeriksaan Permohonan Kredit Pemeriksaan permohonan kredit diidentifikasi melalui pemeriksaan keabsahan permohonan dengan kelengkapannya, pemeriksaan administrasi dan diikuti dengan pemeriksaan tentang keadaan benda jaminan, letak, luas, batas-batasnya dan lain-lain yang dirasa perlu. Sedangkan untuk badan usaha, bank melakukan pemeriksaan kelayakan terhadap berbagai aspek diantaranya :

1) Aspek Manajemen Pengurus atau pimpinan perusahaan harus orangorang yang kepribadiannya tidak diragukan, berjiwa wira swasta serta mempunyai pengetahuan yang cukup mengenai bidang usahanya.

2) Aspek Pemasaran Barang dan jasa yang akan dihasilkan harus mempunyai prospek pemasaran yang baik.

c. Analisa Kredit Adapun analisis pemberian kredit yang dilakukan oleh BPR Batang Kapas meliputi analisis 5C

1. Waktu atau Karakter ( Character) Untuk lebih mengetahui karakter calon debitur, analisis kredit yang dilakukan oleh PT. BPR Batang Kapas yaitu melalui wawancara terhadap calon debitur dan meminta informasi dari Bank Indonesia melalui media yang telah disediakan secara on-line.

2. Capacity Penilaian dari kemampuan mengajukan permohonan kredit PT. Bank Negara Indonesia (Persero) Tbk, KCU Bukittinggi melakukan kunjungan ke lokasi usaha dan juga berdasarkan informsi dari pihak ke tiga lainnya. 
3. Capital Penilaian terhadap permodalan ( capital) calon debitur dapat diketahui analisis kredit dari lapoaran keuangan calon nasabah, serta PT. Bank Negara Indonesia (Persero) Tbk, KCU Bukittinggi melihat keadaan dan situasi usaha nasabah untuk beberapa tahun yang lalu, saat ini dan kemungkinan untuk proyesksi pada masa yang akan datang.

4. Condition of Economy Penilaian terhadap usaha calon debitur, PT. Bank Negara Indonesia (Persero) Tbk, KCU Bukittinggi melihat bagaimana keadaan usaha debitur apakah aman atau tidak, dengan melihat dan meninjau keadaan usahanya dari beberapa tahun terakhir,sekarang dan masa yang akan datang. Agar mengurangi terjadinya kredit bermasalah atau kredit macet

5. Collacteral Agunan dibutuhkan oleh PT. Bank Negara Indonesia cabang Bukittinggi untuk berjaga-jaga atas kemingkinan terjadinya penyimpanagan penilaian terhadap faktor diatas, yang mengakiabat tidak sanggupnya nasabah untuk membayar kembali pinjaman dari usaha atau proyek yang dibiayai. d. Persetujuan Kredit Apabila sudah dilakukan analisa kredit, selanjutnya adalah persetujua kredit, persetujuan kredit oleh BPR Batang Kapas mencakup : 1. Jumlah uang yang diterima 2. Jangka waktu kredit. 3. Biaya-biaya yang harus dibayar. Dalam tahap persetujuan kredit, bank mengambil keputusan atas permohonan kredit disetujui atau ditolak. e. Realisasi Kredit Realisasi kredit diberikan setelah disetujui kreditnya oleh pejabat bank yang berwenang, dengan membuka rekening tabungan di PT. Bank Negara Indonesia Bukittinggi. Pencairan atau pengambilan uang dari rekening sebagai realisasi dari pemberian kredit dapat diambil sesuai ketentuan dan tujuan kredit yang akan digunkan oleh debitur. f. Pengawasan Kredit Setelah kredit diberikan, maka tugas PT. Bank Negara Indonesia cabang Bukittinggi selanjutnya adalah dilakukan pengawasan kredit yang mencakup upaya memeriksa kredit yang diberikannya. Apakah semua yang terjadi sesuai dengan rencana yang ditetapkan, perintah yang dikeluarkan dan prinsip yang dianut, juga dimaksud untuk mengetahui kelemahan dan kesalahan agar dapat dihindari kejadiannya di kemudian hari

\section{Mekanisme Pencairan Kredit Usaha Rakyat (KUR) pada PT. Bank Negara Indonesia (Persero) Tbk, KCU Bukittinggi}

Adapun mekanisme pemberian dana kredit usaha rakyat pada PT. Bank Negara Indonesia KCU Bukittinggi untuk calon debitur yang ingin mengajukan, yaitu sebagai berikut:

1. Tahap Pengenalan Atau Pendekatan

Yaitu tahap dimana pemohon meminta penjelasan mengenai ketentuanketentuan atau syarat-syarat permohonan kredit. Pada tahap ini deskman akan menjelaskan semua keterangan mengenai jenis kredit, sistem bunga dan akan menjawab semua pertanyaan yang diajukan sehingga tidak adanya keraguan dalam diri pemohon kredit. 
2. Tahap Permohonan Kredit

Pemohon kredit akan mengajukan permohonan dengan membawa semua syarat yang telah dijelaskan deskman. Berkas-berkas yang dibawa pemohon kredit yaitu :

a. Surat permohonan kredit

b. KTP (Suami dan Istri)

c. Surat Keterangan Usaha

d. Surat Kelakuan baik dari Polisi atau Walinagari setempat

e. Kartu Keluarga

f. Laporan Keuangan Usahanya

g. Jaminan (Agunan)

Semua berkas dan persyaratan tersebut dibawa ke meja deskman untuk diperiksa kelengkapannya sebelum diserahkan kepada mantra kredit.

3. Tahap Analisa Kredit

Jika semua syarat lengkap maka dilakukan analisa terhadap pemohon kredit baik bersifat keuangan ataupun nonkeuangan (sesuai dengan analisa yang telah dijelaskan sebelumnya), tujuannya untuk mengetahui keadaan usaha pemohon secara langsung. Dalam hal ini mantri kredit akan terjun ke lapangan 5 untuk melihat langsung usaha pemohon kredit, menilai apakah usaha tersebut layak untuk diberikan kredit atau tidak. Selain itu, mantri kredit juga melakukan wawancara terhadap pemohon maupun pihak lain yang bisa memberikan keterangan lengkap dan sesuai dengan kenyataan.

4. Tahap Persetujuan Kredit

Setelah mantri kredit selesai melakukan semua analisa, maka semua berkas akan diserahkan kepada deskman. Deskman akan membawa berkas dan hasil analisa kepada kepala unit. Diterima atau tidaknya permohonan kredit tergantung keputusan kepala unit dan hasil analisa dari mantri kredit.Biasanya keputusan kredit mencakup jumlah kredit yang akan diterima, jangka waktu kredit dan biaya-biaya yang harus dibayar oleh debitur.

5. Administrasi

Deskman akan melakukan pencatatan secara sistematis terhadap data pemohon dan dokumen-dokumen kelengkapan pengajuan permohonan kredit sebagai arsip bagi bank.

6. Realisasi Kredit (Pencairan Kredit)

Setelah kredit disetujui dan administrasi dilakukan, maka deskman akan menyerahkan sebuah slip untuk mencairkan kredit sesuai nominal yang diputuskan yang akan dibawa debitur kepada teller. Pencairan ini dapat dilakukan dengan menerima secara langsung ataupun ditransfer ke rekening debitur.

7. Pengawasan Kredit

Setelah kredit dicairkan dan diterima debitur, maka mantra kredit akan bertugas dalam mengawasi dan memantau usaha debitur. Pengawasan kredit merupakan proses internal control and continue control. Pengawasan kredit yang dilakukan oleh PT. Bank Rakyat Indonesia (Persero) Tbk Unit Panti dua cara yaitu: 
a. On Site Monitoring (Pengawasan Langsung)

Pengawasan yang dilakukan oleh mantri kredit dengan secara langsung mendatangi tempat usaha debitur secara rutin setiap 3 bulan sekali. Tujuan dari pengawasan ini yaitu:

1) Meneliti kebenaran data/keterangan yang disampaikan debitur.

2) Meneliti secara langsung usaha debitur.

3) Sacara psikologis, mengingatkan debitur bahwa pihak bank memberikan perhatian atas usaha debitur.

4) Mendidik debitur untk menyampaikan laporan sesuai dengan kenyataan yang ada.

b. On Desk monitoring (Pengawasan Tidak Langsung)

Pengawasan pasif yang dilakukan mantri kredit yaitu melalui instrumen administratif yang dapat memberikan informasi mengenai gejala-gejala penyimpangan yang berdampak terhadap kolektibilitas kredit. Hal ini dapat dilihat dari laporan keuangan yang diberikan debitur, apakah laporan tersebut sesuai dengan kenyataan atau hanya rekayasa.

8. Pelunasan Kredit

Debitur membayar semua kewajibannya kepada bank sesuai dengan kesepakatan. Pembayaran dilakukan secara angsurang yang dibayar per bulan dan terdiri dari angsuran pokok ditambah angsuran bunga.(Widayati, 1998)

Persyaratan dalam Pemberian Kredit BNI Wirausaha (BWU)

Dalam hal persyaratan dan legalitas calon debitur tergolong sama karena dalam setiap pengajuan kredit tidak ada yang membedakan antara Kredit Usaha Rakyat (KUR) dengan BNI Wirausaha (BWU)

\section{Mekanisme Pencairan Kredit BNI Wirausaha (BWU) Pada PT. BNI KCU Bukittinggi}

Adapun mekanisme pemberian dana kredit BNI Wirausaha pada PT. Bank Negara Indonesia KCU Bukittinggi untuk calon debitur yang ingin mengajukan, yaitu sebagai berikut:

a. Permohonan kredit

Tahap pertama dari prosedur pemberian kredit adalah adanya pengajuan surat permohonan kredit oleh calon debitur yang diajukan secara tertulis oleh penyelia pemasaran kredit

b. Pengumpulan data

Setelah surat permohonan kredit diterima dari calon debitur maka dilakukan registrasi pada buku permohonan kredit

c. Analisa kredit

Dalam analisa kredit diperlukannya data-data tersebut diatas serta data lain yang diperlukan akan dilakukan oleh Account Officer (AO). Adapun data kredit pada umumnya yang dibutuhkan oleh pihak bank terdiri dari beberapa aspek yakni hukum, manajemen, sosial ekonomi, pemasaran, teknik produksi, jaminan dan keuangan. Selanjutnya data tersebut dilakukan pemeriksaaan dan verifikasi.

d. Komite kredit

Komite kredit adalah salah satu team dalam proses pemberian kredit yang anggotanya terdiri dari Account Officer atau analisis kredit, administrasi 
kredit dan kepala bagian (KABAG), kredit serta direksi untuk pengambilan kredit.

e. Keputusan Komite Kredit

Setelah kredit diputuskan disetujui, ditolak atau ditangguhkan, maka segera dibuatkan surat penegasan atau pemberitahuan kepada pemohon. Apabila pemohon kredit disetujui maka harus dibuatkan surat penegasan kepada pemohon kredit BWU

f. Pengikatan kredit

Pengikatan kredit maksudnya disini adalah pengikatan secara notarill yaitu perjanjian antara nasabah calon debitur dengan pihak notaris dalam persetujuan penyaluran kredit serta pengikatan dibawah tangan maksudnya yaitu perjanjian hitam di atas putih antara calon debitur dengan penyelia pemasaran.

g. Penutupan asuransi

Penutupan asuransi yang dilakukan untuk mengurangi resiko yang kemungkinan timbul di kemudian hari karena adanya kesalahan dalam kelengkapan file persyaratan kredit yang akan di asuransikan.

h. Realisasi

Realisasi kredit baru dapat dilakukan apabila semua dokumen yang diberikan sudah benar apa belum sesuai dengan persyaratan yang diberikan oleh bank untuk calon debitur yang mengajukan kredit.

i. Dokumentasi

Pekerjaan yang dilakukan ketika semua persyaratan telah dilengkapi dan langkah-langkah telah dilakukan sebagai bukti bahwa calon debitur telah melakukan sebuah transaksi kepada pihak bank dan terikat dengan peraturan bank yang berlaku

\section{SIMPULAN}

Berdasarkan hasil penelitian yang telah dilakukan penulis pada PT. Bank Negara Indonesia cabang Bukittinggi maka dapat diambil beberapa kesimpulan sebagai berikut :

1. Kredit Modal Kerja (KMK) yaitu kredit yang diberikan kepada perorangan atau lembaga usaha untuk mengembangkan usaha menjadi lebih besar lagi, tentunya syarat yang harus dipenuhi usaha yang telah berjalan selama kurang lebih dari 1 tahun

2. Bahwa dalam pengajuan pemberian kredit modal kerja (KMK) dokumendokumen yang dibutuhkan dalam pemberian kredit modal kerja harus lengkap dan terlampir semua agar pengajuan kredit terealisasi.

3. Mekanisme pemberian kredit modal kerja yang dilakukan oleh PT. Bank Negara Indonesia (Persero) Tbk, KCU Bukittinggi sudah dapat tersalurkan dengan efektif dan efesien. Para calon debitur harus mengikuti prosedur yang sudah ditetapkan oleh PT. Bank Negara Indonesia (Persero) Tbk, KCU Bukittinggi demi kelancaran dalam proses pemberian kredit.

4. PT. Bank Negara Indonesia (Persero) Tbk, KCU Bukittinggi di dalam memberikan pinjaman masih terdapat hambatan terutama dalam 
kelengkapan administrasi harus yang harus dipenuhi oleh calon debitur. Kendala-kendala yang dihadapi tersebut seperti tidak terlampirnya, Surat Izin Usaha Perusahaan (SITU), Tanda Daftar Perusahaan (TDP)

\section{UCAPAN TERIMA KASIH}

Terimaksih penulis sampaikan kepada

1. Kepada kedua orang tua yang selalu memberikan dukungan baik secara moril maupun materil

2. Direktur AKBP beserta prodi AKBP yang telah memberikan kesempatan kepada penulis untuk melakukan penelitian ini

3. Dosen pembimbing yang telah memberikan arahan dan bimbingan hingga tugas akhir ini bisa terselesaikan

4. Pimpinan PT. Bank Negara Indonesia (Persero) Tbk, KCU Bukittinggi yang telah mengizinkan penulis dalam memperoleh informasi beserta pengambilan data

5. Semua pihak yang telah memberikan dukungan dan bantuannya dalam penyelesaian tugas akhir ini

\section{DAFTAR PUSTAKA}

Afriyeni, A. (2009). Analisis Pengaruh Pemberian Kredit Terhadap Profitabilitas PT. Bank Pembangunan Daerah (BPD) Sumatera Barat. Jurnal KBP, 1(2), 113.

Afriyeni, A., \& Putra, Y. E. (2019). Analisis Faktor-Faktor Yang Mempengaruhi Tingkat Pengembalian Kredit Usaha Rakyat (KUR) PT. Bank Rakyat Indonesia (BRI) Unit Talang Cabang Solok. https://doi.org/10.31219/osf.io/crfpg

Amelia, L., \& Marlius, D. (2018). Pengendalian Kredit Dalam Upaya Menciptakan Bank Yang Sehat Pada PT. Bank Pembangunan Daerah Sumatera Barat Cabang Utama Padang. https://doi.org/10.31227/osf.io/kpc64

Alanshari, F., \& Marlius, D. (2018). Prosedur Pemberian Kredit KPR Pada PT. Bank Tabungan Negara (Persero) TBK Cabang Pembantu Bukittinggi. https://doi.org/10.31227/osf.io/rsfhc

Darmawanto, \& Fernos, J. (2019). Prosedur Pemberian Kredit Pada Bank Nagari Cabang Sijunjung. https://doi.org/10.31227/osf.io/psqfy

Efriani, M. (n.d.). Aktivitas pemberian kredit usaha pada pt. bank perkreditan rakyat batang kapas, $1-10$.

Farisi, K., \& Saifi, M. (2016). Analisis Sistem dan Prosedur Pemberian Kredit Modal Kerja Dalam Rangka Mendukung Pengendalian Kredit Bnak. Administrasi Bisnis, 30(1), 117-124. 
Herman, U., \& Widayati, R. (n.d.). Penyelesaian kredit bermasalah pada pt. bank perkreditan rakyat (bpr) nagari kasang, 1-14.

Ikbal, M., \& Marlius, D. (2017). Pengaruh Jumlah Taksiran Dan Uang Pinjaman Terhadap Laba Bersih Pada PT. Pegadaian (UPC) Gurun Laweh. https://doi.org/10.31227/osf.io/uch4a

Maswatu, A. G., Pelleng, F., \& Tampi, D. (2003). Analisis Sumber dan Penggunaan Modal Kerja Pada pt. bank tabungan negara, (persero) tbk. cab. manado. Administrasi Bisnis, 1(2), 1-12.

Purwatiningsih, A. A. (2015). Pengaruh Kredit Usaha Rakyat (KUR) Terhadap Pendapatan Pelaku Usaha Mikro Kecil dan Menengah.

Rakyat, B., Persero, I., Unit, T. B. K., \& Widayati, R. (1998). Pelaksanaan Penyaluran Kredit Pada, (10).

Ratnaningtyas, W. (2016). Mencegah Terjadinya Kredit Bermasalah ( Studi Kasus Pada PT . Bank Rakyat Indonesia ( Persero ), Tbk . Cabang Kawi Malang ), 39(2), 24-33.

Rina Malinda, moch. Dzulkirom, D. (n.d.). Evaluasi Pengendalian Manajemen Pemberian Kredit Modal Kerja Dalam Upaya Meminimalkan Non Performing Loan ( Npl ), 1-12.

Shanjaya, A. R., \& Marlius, D. (2017). Peranan Laporan Keuangan Dalam Kebijaksanaan Pemberian Kredit Kepada Calon Nasabah Pada PT. BPR Batang Kapas. https://doi.org/10.31227/osf.io/uxmg6

Setyawan, A. (2017). Analisis Prosedur Pemberian Kredit. Simki-Economic, 01(08), 14-16.

Syahwier, C. A. (2013). Peranan Perbankan Bagi Pengembangan Lembaga Keuangan Mikro. Jurnal Ekonomi Dan Keuangan, Vol.1(2), 1-12.

Widayati, R. (2019). Aktivitas Pemberian Kredit Komersil Pada Bank Nagari Cabang Sijunjung. https://doi.org/10.17605/OSF.IO/QTVZ9

Widayati, R. (2019). Pelaksanaan Kredit Pada Bank Perkreditan Rakyat LPN Pasar Baru Durian Sawahlunto. https://doi.org/10.17605/OSF.IO/5HPAB

Widayati, R. (2019). Upaya Penanganan Kredit Bermasalah Pada Bank Nagari Cabang Utama Padang. https://doi.org/10.17605/OSF.IO/YJ3KN

Widayati, R. (2019). Aktivitas Pemberian Kredit Usaha Pada PT. Bank Perkreditan Rakyat Batang Kapas. https://doi.org/10.17605/OSF.IO/EDPN4 
WijayaDenda. (2001). Manajemen Perbankan. Edisi Revisi Sembilan, 25. https://doi.org/2009 